\title{
1 Below ground matters: Urban soil rehabilitation increases \\ 2 tree canopy and speeds establishment
}

\section{Abstract}

$4 \quad$ Urban land development frequently destroys soil structure and removes organic matter, limiting

5 tree growth. Soil rehabilitation has potential to improve soil quality but the long-term

6 effectiveness and consequences for tree growth are poorly documented. We evaluated growth,

7 canopy development, and physiological response of five tree species over six years to soil

8 rehabilitation in an experimental site pre-treated to replicate typical land development. A

9 corollary experiment evaluated growth and establishment of three additional species one year

10 after rehabilitation in highly urbanized sites in Arlington County, Virginia. Plot study soil

11 treatments were: typical practice (TP) (10 cm topsoil replaced); enhanced topsoil (ET) (topsoil +

12 rototilling); profile rebuilding (SPR) (compost amendment via subsoiling to 60-cm depth +

13 topsoil + rototilling); and undisturbed (UN) (agricultural land with no pre-treatment). In

14 Arlington, SPR was compared with conventional site preparation (topsoil replacement). Overall,

15 trees grew more rapidly in SPR soils and soil depths immediately below the surface $(\sim 15-30 \mathrm{~cm})$

16 were most affected by SPR, which reduced soil bulk density between 0.19 and $0.57 \mathrm{Mg} \mathrm{m}^{-3}$

17 compared to nonrehabilitated soils. After six years, both trunk cross-sectional area and canopy

18 area of plot-study trees in SPR soils matched or surpassed those in undisturbed soil for all

19 species except $Q$. bicolor while canopy area increased by as little as $2 \%(Q$. bicolor $)$ to as much

20 as $84 \%$ ( $U$. 'Morton'). In Arlington, SPR resulted in $77 \%$ trunk cross-sectional area growth after

21 one year. Plant and soil water relations may also be altered by rehabilitation, possibly

22 contributing to its potential as a tool for stormwater mitigation. Rehabilitation accelerates 
23 establishment and growth of urban trees planted in compacted urban soils indicating that the

24 below-ground environment should be a key component in policy and decision making.

25 Key words: compost; land development; organic amendments; soil carbon; soil compaction;

26 subsoil; soil remediation; soil temperature; tillage 


\section{Introduction}

30 As global urban land cover continues to increase (Seto et al., 2012), the need to effectively

31 sustain tree canopy on soils disturbed by this land conversion becomes more critical. Tree

32 canopy provides a host of ecosystem services (Bolund and Hunhammar, 1999; Nowak and

33 Dwyer, 2007; Roy et al., 2012), yet urban canopy cover is difficult to establish (Harris, 2007;

34 Roman et al., 2014) and maintain (Nowak and Greenfield, 2012). Consequently, expected

35 environmental and social benefits from tree planting are seldom achieved in highly disturbed

36 sites where tree growth and survival rates are poor.

37 Urban tree canopy is frequently viewed as a policy tool to improve environmental quality

38 (Chesapeake Executive Council, 2003; Nowak, 2006; McGee et al., 2012). Yet despite such

39 policy efforts, urban canopy cover often does not increase; rather there is evidence of widespread

40 canopy shrinkage (Nowak and Greenfield, 2012). This decline is in large part attributed to land

41 use change (Nowak et al., 2004), but revegetation of developed land is also necessary for

42 counteracting these trends. Unfortunately, poor soil quality may be among the most significant

43 limiting factors for optimal tree survival and growth. Both direct disturbance and the disruption

44 of soil development processes are major factors that degrade urban soils (Pavao-Zuckerman,

45 2008). During the change from rural to urban land uses, soils are typically degraded by processes

46 intended to facilitate building construction, such as vegetation clearing, topsoil removal, grading,

47 and compaction (Randrup and Dralle, 1997). These typical land development practices adversely

48 influence soil physical characteristics desirable for ecosystem service provision (Chen et al.,

49 2014b), and impede tree growth and canopy establishment (Gilbertson and Bradshaw, 1990; Jim, 50 1998). 
51 As a consequence of this disruption, there is considerable interest in improving the ability of

52 disturbed sites to support tree growth and establishment (Cogger, 2005; Sloan et al., 2012). For

53 planted trees, the establishment period encompasses the first few years after planting and is

54 generally considered a high risk period in terms of tree survival (Harris, 2007), although

55 mortality rates vary widely due to the vagaries of quality control during the planting process

56 (e.g., nursery stock quality, transport and handling, irrigation regimes) and the wide range of

57 vulnerabilities that can exist at urbanized sites (e.g., soil conditions, vandalism, exposure to

58 vehicular collisions, etc.; for examples, see Gilbertson and Bradshaw, 1990; Nowak et al., 1990;

59 Roman and Scatena, 2011). Following establishment, site conditions continue to affect tree

60 growth. Soil compaction hinders tree root exploration of soil (Day and Bassuk, 1994; Kozlowski,

61 1999; Day et al., 2000) and is associated with significantly reduced canopy dimensions of urban

62 trees (Day and Amateis, 2011). Although the potential of soil compaction to reduce tree canopy

63 is well recognized, quantitative assessments of increased canopy growth resulting from soil

64 management practices that reduce compaction and improve soil quality are scarce. In addition,

65 the organic matter loss associated with land development may impair rebuilding soil physical

66 properties over time because of its essential role in the development of soil structure (Six et al.,

67 2004) and in sustaining water and nutrient supplies (Hillel, 1982), suggesting that a soil

68 rehabilitation technique that both reduces compaction and sets the stage for long-term

69 improvement of soil quality is needed. Such a soil rehabilitation technique would be a novel

70 approach to post-development site preparation, since typical practices are no more than a shallow

71 covering of topsoil. A quantitative analysis of the effects of differing post-land development soil

72 management practices on urban tree canopy development could then inform land development

73 policies and practices. 
74 Local government may rely on tree ordinances protection and replacement ordinances for new

75 development to maintain or increase community tree canopy cover. In some instances, increasing

76 tree canopy may be needed to meet regulatory requirements concerning water and air quality.

77 However, policy rarely distinguishes between development practices that employ improved soil

78 protection and rehabilitation and those that do not—even though these factors will likely strongly

79 influence canopy outcomes. Quantifying the effects of soil rehabilitation on tree canopy

80 development would be a useful tool for urban foresters seeking to include the effects of soil

81 quality on the growth potential for urban and landscape trees in management decisions and

82 contribute to effective and equitable policy tools for increasing canopy. Soil restoration is also a

83 recognized component of sustainable practice at the site level [e.g., the voluntary certification

84 standards set forth by the Sustainable Sites Initiative (SITES ${ }^{\mathrm{TM}}$ ) (Sustainable Sites Initiative,

85 2014)], but measures of the impact of rehabilitation practices that contribute to soil restoration

86 are needed. The heterogeneous nature of urban landscapes and the impact of fine-scale land

87 management decisions (Mincey et al., 2013) make a strong case for including site-level

88 decisions, such as soil management, in urban tree canopy policy and planning.

89 Soil improvement usually includes some degree of amendment with organic materials such as

90 compost. Soil organic amendments can improve water holding capacity (Khaleel et al., 1981;

91 Rawls et al., 2003), accelerate C storage (Chen et al., 2013) and increase hydraulic conductivity

92 (Boyle et al., 1989; Martens and Frankenberger, 1992; Pitt et al., 1999; Brown and Cotton, 2011;

93 Chen et al., 2014b). However, many amendment studies focus on surface applications or shallow

94 incorporation of organic amendments (e.g., Cogger, 2005 and Sloan et al. 2012), which likely do

95 not address the deeper soil compaction that may be present in urbanized land. In this study we

96 examine the effects on tree establishment and growth of "soil profile rebuilding" (Day et al., 
97 2012), a technique that includes deep incorporation of compost to loosen subsurface soils that are

98 typically compacted during urban development and land use change. We previously reported the

99 effects of this practice on soil properties (Chen et al., 2013; Chen et al., 2014b) and greenhouse

100 gas emissions (Chen et al., 2014a).

101 We evaluated five tree species over six years in response to soil profile rebuilding in comparison

102 with typical development practices and undisturbed agricultural soil at a long-term experimental

103 plot area. Additionally, we measured tree growth and mortality of three additional tree species

104 one year after planting with and without soil profile rebuilding along roadsides and in medians in

105 Arlington County, Virginia. Our objectives were to 1) evaluate whether compaction can be

106 reduced over the long-term in soil damaged by typical land development practices; 2) assess

107 whether soil rehabilitation aids in new tree establishment; and 3) quantify potential gains in tree

108 growth and canopy cover resulting from soil rehabilitation.

\section{Methods}

110 Experiment 1: Experimental Plot Study

111 Study Site and Pre-treatment

112 The long-term study site, in Montgomery County, Virginia USA ( $37^{\circ} 12^{\prime} 1.1844^{\prime \prime} \mathrm{N}$,

$11380^{\circ} 33^{\prime} 48.3768^{\prime \prime} \mathrm{W}$ ), was historically in agricultural use and planted in pasture grass for 12-15

114 years before plot installation. Soils were loams, including Shottower loam (fine, kaolinitic, mesic

115 Typic Paleudults) and Slabtown loam (fine-loamy, mixed, mesic Aquic Paleudalfs) (Galbraith

116 and Donovan, 2005). Twenty-four $4.6 \times 18.3 \mathrm{~m}$ plots were installed in a completely random

117 experimental design $(6$ replications $\times 4$ soil treatments $=24$ plots $)$ as described below. 
118 Prior to treatment installation, all existing vegetation was killed with the herbicide glyphosate.

119 Undisturbed (UN) plots were protected from traffic while all other plots received a scraping and

120 compacting pre-treatment common to current land development practices in the United States.

121 The A horizon (25-30 cm depth) was scraped and stockpiled adjacent to the site on June 19, 2007

122 and the underlying exposed subsoil was then compacted with eight passes of a 4,800 kg sheep's

123 foot vibrating riding compactor to a mean bulk density of $1.95 \mathrm{Mg} \mathrm{m}^{-3}(\mathrm{n}=64, \mathrm{SE}=0.01)$ at 5-

$12410 \mathrm{~cm}$ depth.

125 Soil Treatments

126 Each experimental plot received one of four soil treatments during August-October 2007: 1)

127 undisturbed (UN) no treatment (and no pre-treatment); 2) typical practice (TP), stockpiled

128 topsoil replaced to a uniform depth of $10 \mathrm{~cm}$; 3) enhanced topsoil (ET), same as TP, but topsoil

129 tilled to approximately $12-15 \mathrm{~cm}$ depth to mix its interface with compacted subgrade; and 4) soil

130 profile rebuilding $(\mathrm{SPR}), 10 \mathrm{~cm}$ of composted leaf litter $(\mathrm{C} / \mathrm{N}$ ratio $=15 ; \mathrm{pH}=7.4)$ applied to

131 subgrade followed by subsoiling with a backhoe (adapted from a procedure described by Rolf,

132 1991) to a depth of $60 \mathrm{~cm}$. In this procedure, soil is lifted with the backhoe bucket to

133 approximately $1-2 \mathrm{~m}$ and allowed to fall back to ground, serving to mix components and break

134 clods. Clods greater than approximately $30-45 \mathrm{~cm}$ in diameter are mechanically fragmented with

135 the backhoe bucket. This method of subsoiling was selected because it can be employed in

136 physically constrained urban sites (road medians, near underground infrastructure, etc.).

137 Subsequent sampling with a push tube and observation using minirhizotrons confirmed the

138 presence of veins of compost consistently reached a depth of 35-60 cm. Finally, $10 \mathrm{~cm}$ of

139 stockpiled topsoil was applied and tilled to approximately $12-15 \mathrm{~cm}$ depth. The TP treatment

140 represents typical practice employed by contractors to bring a building site to finish grade and 
141 prepare it for landscaping. Soil profile rebuilding is a soil rehabilitation technique developed

142 specifically for this study intended to facilitate long-term soil improvement, improve tree growth,

143 and enhance soil C sequestration (Day et al., 2012).

144 A 0.76-mm thick, 0.6-m deep root barrier (Deep Root Partners, L.P., San Francisco, California)

145 was installed between adjacent plots in an approximately 0.2 -m-wide trench excavated $0.5 \mathrm{~m}$

146 deep to prevent root growth and soil movement from neighboring plots. Approximately $10 \mathrm{~cm}$ of

147 barrier was left exposed above ground to prevent root growth over the top of the barrier. All plots

148 were covered with straw erosion control blankets to protect them from rain impact and erosion

149 for the first two years. After this time, the soil surface was kept bare by controlling weeds with

150 periodic application of glyphosate and oxyfluoren + pendimethalin.

151 Tree Species

152 Five tree species were planted $3.7 \mathrm{~m}$ apart in a single row in each plot with in-row position

153 randomly assigned: container-grown (26.5 L) Acer rubrum L. and Quercus bicolor Willd.;

154 container-grown (11.4 L) Quercus macrocarpa Michx.; and bare root Ulmus 'Morton'

155 (Accolade $\left.^{\circledR}\right)($ U. japonica (Rehd.) Sarg. $\times$ U. wilsoniana Schneid.), and Prunus 'First Lady' $(P$.

156 xincam Ingram ex R. Olsen \& Whittemore 'Okamé' $\times$ P. campanulata Maximowicz). Container-

157 grown trees were grown in semi-composted $100 \%$ pine bark substrate at a nearby research

158 nursery. Bare-root stock was obtained from J. Frank Schmidt \& Son Company (Boring, Oregon).

159 All trees were planted before leaf out in spring 2008. Q. bicolor and A. rubrum trees were

160 planted between February 28 2008, and March 10 2008, into planting holes two times the width

161 of the container. Ulmus. 'Morton' and Prunus 'First Lady' were planted on March 17, and

162 Q. macrocarpa on April 25 2008, in 70-80 cm diameter holes. 


\section{Soil Measurements}

164 Soil physical and chemical characteristics were characterized in May and June 2008,

165 approximately 8 months after site preparation by collecting undisturbed soil cores $(5-\mathrm{cm} \mathrm{D} \times 5$ -

$166 \mathrm{~cm} \mathrm{H}$ ) at four depths (approximately $2.5-7.5 \mathrm{~cm}, 15-20 \mathrm{~cm}, 30-35 \mathrm{~cm}$, and $51-56 \mathrm{~cm}$ ) at two

167 randomly selected midpoints between trees in each plot. Soil bulk density $\left(\rho_{\mathrm{b}}\right)$ was calculated for

168 each core after oven drying at $105^{\circ} \mathrm{C}$ to a constant weight and the average of the two cores at

169 each depth calculated for each plot. Particle size analysis (PSA) and carbon/nitrogen ratio (C/N)

170 was determined from composites of the two cores at each depth within a plot. $\mathrm{C} / \mathrm{N}$ was analyzed

171 with a Vario MAX CNS macro elemental analyzer (Elementar, Hanau, Germany). In June 2012,

172 bulk density was remeasured using the same procedures.

\section{Growth Measurements}

174 Tree height and trunk diameter were measured with microcalipers in two perpendicular

175 directions at $30 \mathrm{~cm}$ above the soil surface. Trunk cross-sectional area was calculated as

$176 \pi \mathrm{D}_{\mathrm{NS}} \mathrm{D}_{\mathrm{EW}} / 4$, where $\mathrm{D}_{\mathrm{NS}}$ and $\mathrm{D}_{\mathrm{EW}}$ are the two trunk diameters. Measurements were made

177 immediately after planting in spring 2008, then again at the end of the growing season in late

178 November 2008, and each November thereafter until 2013. Canopy projection area was likewise

179 determined by measuring canopy spread in two perpendicular directions using the farthest

180 reaching branch in each direction on March 212009 (before leaf out, representing the previous

181 year's growth), and on subsequent years in November when trees were in full canopy. Trees

182 were lightly pruned on May 22 2009, to promote future structure with the exception of the $U$.

183 'Morton'. For these trees, extremely vigorous shoots were headed back and staked to avoid the

184 possibility of windthrow. In subsequent years, trees were only very lightly pruned to enhance

185 structure as needed. 
187 For all treatments, we measured chlorophyll fluorescence and chlorophyll content index for all

188 species during the first two years after planting and photosynthesis rate and leaf water potential

189 for A. rubrum and Q. bicolor trees only. Measurements for chlorophyll content index (Minolta

190 SPAD 502, Spectrum Technologies, Plainfield, Illinois) were made on all species using two sun-

191 exposed leaves per tree on July 11 2008, September 20 2008, and August 14 2009. Chlorophyll

192 fluorescence measurements were obtained from all species after sun-exposed leaves (one per

193 plant) were dark-adapted for 20 min prior to measurement of the maximum photochemical

194 efficiency of photosystem II (Fv/Fm) on September 21 2008, and August 182009.

195 Photosynthesis rate was measured for A. rubrum and Q. bicolor trees on one randomly chosen

196 sun-exposed leaf from the outer canopy (3-7 nodes from twig apex) using a portable gas

197 exchange analyzer (Li-6400, Li-cor Biosciences, Lincoln, Nebraska) on May 27 2008,

198 September 13 2008, and September 2 2009. Leaf water potential ( $\psi$ leaf) was measured on one

199 randomly selected leaf (3-7 nodes from twig apex) every two hours beginning at $0600 \mathrm{HR}$ and

200 ending at $2000 \mathrm{HR}$ using a pressure chamber (Model 600 Pressure Chamber Instrument, PMS

201 Instrument Co., Albany, Oregon, USA) on July 19 2008, October 1 2008, and August 152009.

202 Data were plotted for each individual replication and the area under the curve (hereafter referred

203 to as integrated whole day water stress; I- $\Psi$ ) was calculated using the trapezoidal rule (Zill, 204 1985).

205 Experiment 2: Arlington Study

206 Study Site

207 The study was conducted in Arlington, Virginia, USA where 25 plots were located along two

208 main roads, South Walter Reed Drive near its intersection with South Four Mile Run Drive 
209 (38.847046, -77.094800) and North George Mason Drive beginning at the intersection of $15^{\text {th }}$

210 Street and continuing to the intersection with Lee Highway $(38.895427,-77.133510)$. Each plot

211 consisted of an unpaved area in a center median or alongside the road created as a part of a city

212 traffic calming project. Arlington is located in the Fall Zone (Coastal Plain cappings over

213 Piedmont) physiographic region of Virginia and has a temperate climate, with an average annual

214 temperature of $13.17^{\circ} \mathrm{C}$, and average annual rainfall $1085 \mathrm{~mm}$.

215 Site soils are classified as urban land complex but may retain some characteristics of the pre-

216 development soils (Effland and Pouyat, 1997) which likely include Sassafras series (Fine-loamy,

217 siliceous, semiactive, mesic Typic Hapludults) and Neabsco series (Fine-loamy, siliceous,

218 semiactive, mesic Typic Fragiudults) at the Walter Reed plots, and Glenelg series (Fine-loamy,

219 mixed, semiactive, mesic Typic Hapludults) at the George Mason plots. The Sassafras series is

220 well drained with moderate to high saturated hydraulic conductivity $\left(\mathrm{K}_{\mathrm{sat}}\right)$ and loamy

221 fluviomarine sediment parent material. The Neabsco series is very deep and moderately well

222 drained. Particle size analysis at $0-15 \mathrm{~cm}$ indicated soils were sandy loams while deeper horizons

223 were loams or sandy clay loams.

224 Experimental Design and Plot Placement

225 Tree species and locations were selected by the Arlington Division of Transportation, with

226 Ginkgo biloba L. being planted in the medians along N George Mason Drive, Quercus coccinea

227 Muenchh in streetside plantings on N George Mason Drive, and Cercidiphylum japonicum

228 Siebold \& Zucc. in streetside plantings on S Walter Reed Drive. Treatments were then randomly

229 assigned to plots resulting in 13 control plots and 12 SPR plots. Fifteen of the plots were either

230 parallel parking spaces or left-turn lanes, and were under pavement prior to their conversion to 
231 sidewalk "bump-out" tree pits or median plantings. The remaining 10 plots were not previously

232 under pavement and were either on hillsides near intersections, in existing tree planting areas, or

233 separated from the street by the sidewalk. All plots were within $5 \mathrm{~m}$ of the road.

\section{Soil Treatments}

235 Plots were prepared by a contractor with either soil profile rebuilding (SPR) as described in

236 Experiment 1 (note that contractor did not fully meet specifications, see Results below) or left as

237 prepared with the standard site preparation method used by Arlington County Parks and

238 Recreation (control), where approximately $15 \mathrm{~cm}$ topsoil (sandy loam, $\mathrm{pH}$ of 5.5 to 6.5,

239 minimum organic content of $1 \%$, and free of debris $>1.3 \mathrm{~cm}$ ) is placed over existing subsoil to

240 bring the soil up to curb grade.

241 Tree Planting

242 All plots were planted with one of the three tree species in October 2012 with existing soil as

243 backfill, each plot had between 1 and 4 trees (total 25 plots and 36 trees). Trees were balled and

244 burlapped and approximately $60 \mathrm{~mm}$ trunk diameter at $15 \mathrm{~cm}$ above the root ball. Trees were not

245 staked and $10 \mathrm{~cm}$ of shredded hardwood bark mulch was applied around the trees in a $1.2 \mathrm{~m}$

246 diameter ring. The remainder of the plot surface was turf. Because the SPR treatment disturbed

247 surrounding soil and sod, new sod was installed after tree planting.

248 Tree Growth

249 Trunk diameter, canopy, and height were measured in March 2013 and February 2014

250 representing size at planting and after one growing season. Trunk diameter was measured at

$25115 \mathrm{~cm}, 30 \mathrm{~cm}$ and $130 \mathrm{~cm}$ from ground level, corresponding to caliper and diameter at breast

252 height measurements common in the forestry and horticulture professions. Height was measured 
253 with a Vertex III hypsometer (Haglöf, Långsele, Sweden). Canopy was calculated by measuring

254 crown width in two dimensions and height of lowest branch. Individual trees in plots with more

255 than one tree were treated as subsamples.

256 Infiltration Measurements

257 Infiltration, as near-saturated hydraulic conductivity ( $\left.\mathrm{K}_{\text {near }}\right)$ of the soil matrix (Zhang, 1997), was

258 measured using a mini disk tension infiltrometer (Decagon Devices, Inc., Pullman, Washington)

259 with $2 \mathrm{~cm}$ tension at approximately $1 \mathrm{~m}$ from trees in each plot on May 15-16, 2014. Turf was

260 trimmed at soil level and three measurements (treated as subsamples) were taken at each plot.

261 Soil Temperature

262 Temperature sensors (Hobo ${ }^{\circledR}$ Tidbit v2, Onset, Bourne, Massachusetts) were installed $20 \mathrm{~cm}$

263 below the soil surface in the center of each plot but at least $1 \mathrm{~m}$ from the nearest tree on June 24-

264262013 , and logged temperature readings $\left( \pm 0.2^{\circ} \mathrm{C}\right)$ every 15 minutes until they were removed on

265 June 212014.

266 Soil Sample Collection

267 Soils were sampled for total C, aggregate stability, bulk density and aggregate-associated C on

268 November 1-3 and 25 2013. Soil cores were obtained with a JMC Environmentalist's Subsoil

269 Probe (ESP; Clements Associates, Inc, Newton, Iowa). This instrument was driven into the soil

270 manually with a slide hammer, and penetrated the soil to a depth of $92.8 \mathrm{~cm}$. Cores were

271 removed by jacking the sampling tube out of the ground resulting in a continuous core $2.9 \mathrm{~cm}$ in

272 diameter. As an artifact of core extraction, the soil sample can become slightly compressed. To

273 adjust for this, the amount of sample compression was measured for every $15 \mathrm{~cm}$ that the

274 sampler was advanced into the ground, the last interval being $17.8 \mathrm{~cm}$. In some instances, rocks 
275 blocked the opening of the sampler, falsely indicating high compression for a section of the

276 sample. Samples were retaken in such cases. Compression of each 15 or $17.8 \mathrm{~cm}$ section was

277 calculated and recorded as a percentage. Cores were kept on ice during transport and then stored

278 at $4^{\circ} \mathrm{C}$ for later processing for analysis of particle size distribution, aggregate stability, total $\mathrm{C}$

279 and aggregate associated C.

280 In addition, four soil cores $(5-\mathrm{cm} \mathrm{D} \times 5-\mathrm{cm} \mathrm{H})$ were taken from each plot with a slide hammer at 281 approximately $5-10 \mathrm{~cm}, 20-25 \mathrm{~cm}, 42.5-47.5 \mathrm{~cm}$, and $72.5-77.5 \mathrm{~cm}$ and used for analysis of $\rho_{\mathrm{b}}$

282 and $\mathrm{K}_{\text {sat. }}$ Some depths at some plots could not be sampled due to excessive stones resulting in

283 only 83 of the 96 planned samples being collected. The presence of stones was not treatment

284 related and these samples were treated as missing data.

285 Soil Sample Analysis

286 Compression percentages recorded in the field were used to separate the samples into 4 depth

287 increments corresponding to $0-15,15-30,30-60$ and $60-90 \mathrm{~cm}$ depths in the field. Particle size

288 distribution was analyzed from these segments from 8 plots representative of the range of soils

289 included in the study.

290 Saturated hydraulic conductivity $\left(\mathrm{K}_{\text {sat }}\right)$ of the $5-\mathrm{cm}$ soil cores was measured in the lab in January

2912014 using the constant head method described in Klute and Dirksen (2003). Five of the 83 cores

292 were not measured due to rocks protruding beyond the end of the aluminum sleeve. After cores

293 were measured for $\mathrm{K}_{\text {sat, }}$ samples were oven dried for 24 hours at $105^{\circ} \mathrm{C}$ and weighed. Bulk

294 density was calculated in both the $\rho_{\text {fine-earth }}$ (density of the soil between rock fragments in the

295 sample) and $\rho_{\text {hybrid }}$ (density of the soil without the mass of rock fragments but with the entire

296 sample volume) forms described by Throop et al. (2012), although rock volume was calculated 
297 from the mass of washed separated rocks (assumed particle density of $2.65 \mathrm{~g} / \mathrm{cm}^{3}$ ), instead of

298 being measured by displacement. The $\rho_{\text {hybrid }}$ bulk density was used for estimation of areal C

299 densities, because the density of the soil when rocks are considered voids accurately accounts for

300 the proportion of the soil-rock matrix that can contribute to soil C, while $\rho_{\text {fine-earth }}$ is used for

301 discussion of changes in bulk density, as the density of the fine-earth fraction is most related to

302 root growth restriction.

303 Aggregate size distribution was determined from samples extracted from each of the four layers

304 in the deep continuous cores described above using the wet sieving methods described in Six et

305 al. (1998). Fifty g $( \pm 0.02 \mathrm{~g})$ samples were placed on $2 \mathrm{~mm}$ sieves and slaked by being rapidly

306 submerged in deionized water. Samples were allowed to equilibrate for $5 \mathrm{~min}$, then the sieve was

307 moved up and down for 50 strokes (counting both the up stroke and the down stroke) within 2

308 min. Material remaining on the sieve was then washed into labeled aluminum pans. Water and

309 material that had passed though the sieve was then poured onto a $250 \mu \mathrm{m}$ sieve and sieved for 50

310 strokes. Material left on the sieve was washed into a labeled pan and the water and remaining

311 material were poured onto a $53 \mu \mathrm{m}$ sieve, and the process above repeated. Samples were dried at

$31255^{\circ} \mathrm{C}$ for 24 hours or until all water had evaporated from the pans. Sample weights were recorded

313 and soil mean weight diameter was calculated according to this equation:

$314 \mathrm{MWD}=(M>2000 \mu \mathrm{m} \times 5)+(M 250-2000 \mu \mathrm{m} \times 1.125)+(M 53-250 \mu \mathrm{m} \times 0.151)+(M<53 \mu \mathrm{m} \times 0.0265)$

315 Aggregate fractions were corrected for rock and sand content according to Denef et al. (2001)

316 Fractions were ground and dry-sieved to separate rocks, a subsample of the aggregates was

317 placed in sodium hexametaphosphate solution and shaken overnight, and washed through a

$31853 \mu \mathrm{m}$ sieve. Material remaining on the sieve was oven-dried and weighed. 
319 Total $\mathrm{C}$ analysis was performed using dry combustion on an Elementar Variomacro CN

320 Analyzer (Elementar Analysensysteme GmbH, Hanau, Germany), all C was assumed to be

321 organic. Soil core segments were broken apart by hand, mixed, and air-dried before a subsample

322 was ground to be analyzed for total C. After sand corrections were done on aggregate fractions,

323 the ground aggregate fraction samples were also analyzed for aggregate-associated $\mathrm{C}$ using the

324 same CN analyzer. One segment contained lumps of coal and was not included in soil C

325 calculations. Soil C for $90-100 \mathrm{~cm}$ depth was extrapolated based on the $\mathrm{C}$ at the $60-90 \mathrm{~cm}$ depth

326 to calculate total soil organic $\mathrm{C}$ to a $1 \mathrm{~m}$ depth.

327 Statistical Analysis

328 For Experiment 1, soils and physiological data were analyzed via ANOVA in SAS v. 9.2 (SAS

329 Institute, Inc., Cary, North Carolina) followed by mean separation procedures as noted. Multi-

330 year growth data were analyzed with PROC GLIMMIX and repeated measures analysis in SAS

331 v. 9.2 (SAS Institute, Inc., Cary, North Carolina). In Experiment 2, two-sample t-tests were used

332 to analyze differences in soil characteristics between treatments. For tree growth, GLM was used

333 to check for interactions of treatment and species due to the unbalanced design. In both

334 experiments, species were analyzed separately.

\section{Results}

336 Experiment 1: Experimental Plot Study

337 Soil Characteristics

338 Surface soil $(2.5-7.5 \mathrm{~cm}) \rho_{\mathrm{b}} 5 \mathrm{yrs}$ after treatment installation was similar across all treatments

339 (Table 1), although measurements at 8 months had indicated SPR and ET (treatments that

340 included tillage) had slightly lower densities. Treatment effects on $\rho_{\mathrm{b}}$ were most pronounced at 
$341 \quad 15-20 \mathrm{~cm}$ depth, below the added topsoil layer, where SPR had the lowest density, followed by

342 undisturbed soils. For the most part, treatment did not significantly affect $\rho_{\mathrm{b}}$ below $30 \mathrm{~cm}$.

343 Soil pH ranged from 5.1 to 5.8 except in SPR plots, which were slightly higher (6.3-7.1)

344 presumably due to the addition of compost $(\mathrm{pH}=7.4)$. Likewise, $\mathrm{C} / \mathrm{N}$ ratio was relatively

345 consistent (9.7-10.3 in the upper $20 \mathrm{~cm}$ of soil) and decreased with depth, although SPR elevated $346 \mathrm{C} / \mathrm{N}$ ratio slightly.

347 Tree Growth and Survival

348 Tree survival was $100 \%$ with the exception of one SPR red maple that was destroyed by a severe

349 wind storm in July 2012. After six growing seasons, trunk cross-sectional area had increased

350 more rapidly in trees planted in the SPR plots for all species except $Q$. bicolor, where

351 undisturbed plots resulted in larger trees (Fig. 1). Canopy projection area followed a similar

352 pattern, although there was more variability and differences could not always be attributed to

353 treatments (Fig. 2). Trees planted in TP plots were universally smaller in both trunk diameter and

354 canopy than those planted in SPR plots, although in some cases (Q. bicolor) differences were

355 slight or statistical evidence was weak (A. rubrum and Q. bicolor; $\mathrm{p}>0.05$ ). In the case of

356 A. rubrum this can be partly attributed to the death of one of the SPR replicates.

357 Physiological Measurements

358 Soil treatments had no significant effect on mean I- $\Psi$ in the first or second year for either

359 A. rubrum or Q. bicolor except for A. rubrum in 2009 when water stress was greater in the SPR

360 and ET treatments (Table 2). Likewise, photosynthesis rates for all treatments of both A. rubrum

361 and Q. bicolor were low (as might be expected post-transplant) and, for the most part, not

362 significantly different (Table 2). However, in September 2008 Q. bicolor photosynthesis rates in 
363 SPR plots were noticeably higher than in other treatments. Treatment did not affect chlorophyll

364 content index or fluorescence for any species.

365

366 Tree Growth

367 Even after only one growing season, trees planted in SPR plots in Arlington had a 77\% greater

368 average increase in cross-sectional area measured at $15 \mathrm{~cm}$ above ground level than trees in

369 control plots (Fig. 3). This pattern was also observed within species, although there were too few

370 experimental units with G. biloba to perform statistical tests. At $30 \mathrm{~cm}$ and $1.30 \mathrm{~m}$, no

371 differences were observed, likely because of both the small magnitude of increase and high

372 variability due to branching below the measuring point in these young trees. Likewise, there was

373 no evidence of differences in height gain or crown volume increase attributable to treatment.

374 Soil Characteristics

375 During soil analysis, no compost was observed at soil depths below $35 \mathrm{~cm}$. Because soil below

$37630-35 \mathrm{~cm}$ was essentially undisturbed due to improper installation, analyses are focused at the

$377 \quad 15-30 \mathrm{~cm}$ depth. At 15-30 cm depth, $\rho_{\mathrm{b}}$ was significantly lower in SPR plots than in control plots

378 while macro-aggregate-associated $\mathrm{C}$ was greater for both the $250-2000 \mu \mathrm{m}$ and the $>2000 \mu \mathrm{m}$

379 size classes (Table 3). Aggregate-associated C in micro-aggregates $(<250 \mu \mathrm{m})$ was not affected

380 by treatment. Mean aggregate weight diameter (MWD) was used to represent aggregate size

381 distribution (Van Bavel, 1950), but we found no differences in MWD among treatments after one

382 year. In spite of the compost addition associated with SPR, total soil organic C stocks were not

383 statistically different between SPR and control plots. This may be due in part to the

384 heterogeneous nature of the SPR-treated soil vs. the vertical core based sampling scheme

385 employed (Table 3). 
387 Surface soils and surface treatments were similar and no differences in infiltration as measured 388 by $\mathrm{K}_{\text {near }}$ were observed, with an overall mean $\mathrm{K}_{\text {near }}$ of $2.75 \mathrm{~cm} \mathrm{hr}^{-1}$ (SE 0.39). At all depths, $\mathrm{K}_{\text {sat }}$ 389 was generally high, but more importantly $\mathrm{K}_{\text {sat }}$ was highly variable and there were no differences

390 attributable to treatment. Rates varied from zero or near zero to well over $200 \mathrm{~cm} \mathrm{~h}^{-1}$ due to the 391 heterogeneous configuration that is typical of highly disturbed soils.

\section{Soil Temperature}

393 Overall, soil temperature appeared to be very slightly buffered by SPR, although the plots used

394 in this study were too variable in terms of sun exposure to provide overall statistical evidence to 395 document this. Consequently, as a case study, we compared temperature data from two plots that 396 were well matched in terms of proximity, closeness to pavement, and solar exposure during the 397 month of September. Maximum/minimum temperatures recorded over the entire study period in 398 the plots were $31.7 / 0.3^{\circ} \mathrm{C}$ and $31.4 / 0.8^{\circ} \mathrm{C}$ for control and SPR plots respectively indicating an 399 extremely slight buffering of temperature by SPR. Maximum temperatures for both treatments 400 occurred on July 19, 2013 at 6 PM and the minimum on January 31, 2014 for the SPR plot and 401 on February 1 and 2, 2014 for the control. Mean diurnal temperature range was $2.04{ }^{\circ} \mathrm{C}$ (SE 4020.11 ) for controls and $1.84{ }^{\circ} \mathrm{C}$ (SE 0.10$)$ for SPR. One sensor was disturbed by installation of an 403 electrical box soon after it was placed, and was found within $1 \mathrm{~cm}$ of the surface. The maximum 404 and minimum temperatures recorded by that sensor were $48.9^{\circ} \mathrm{C}$ (July 19) and $-2.2^{\circ} \mathrm{C}$ (January 40530 ) indicating the magnitude of temperature extremes possible near the surface. 


\section{Discussion}

407 Overall, establishment was enhanced by SPR as evidenced by increased first year trunk growth

408 in the Arlington study and a similar response over the six years of the plot study. In the plot

409 study, species considered slower to establish (Q. bicolor and Q. macrocarpa) did not begin to

410 display treatment differences until after two or three growing seasons, while more rapidly

411 establishing species began to demonstrate different growth rates after one growing season. This

412 may explain why A. rubrum experienced greater water deficit in ET and SPR treatments after

413 one year, while Q. bicolor showed no such effect. Chen (2014b) found that SPR resulted in

414 lower bulk soil water contents than other treatments, which may have contributed to this effect.

415 Differences in water deficit were not biologically significant, but do suggest that more

416 exploration of the water relations of the plant soil system may be warranted.

417 Overall, soil rehabilitation speeds growth and canopy development of planted trees compared to

418 conventional practices. In the Arlington study, increased growth was only measurable in trunk

419 measurements at $15 \mathrm{~cm}$, as might be expected since the establishment period is usually

420 characterized by root regeneration and minimal shoot growth (Harris, 2007). With the exception

421 of Q. bicolor, long term canopy development was strongly affected by soil treatment, indicating

422 that soil conditions should be considered whenever tree planting is used as a policy tool to

423 address urban tree canopy cover. The clear effect of available soil volume on canopy

424 development has been demonstrated (Grabosky and Gilman, 2004; Day and Amateis, 2011) but

425 this study supports efforts to include soil quality in decision making as well. Trunk size is well

426 correlated with whole tree biomass (McHale et al., 2009), and trunk measurements likewise

427 showed a strong soil treatment effect that did not dissipate over time. The plot study pre-

428 treatment mimicking land development practices is really a base level for development- 
429 associated soil disruption. Many sites will have lower quality fill material and be subjected to

430 significantly more grading resulting in deeper and more severe compaction. Consequently, the

431 net effects of SPR could be greater in many situations.

432 Soil organic amendments are commonly recommended for improving highly disturbed urban

433 soils and are particularly recommended for reducing soil compaction (Cogger, 2005; Sæbø and

434 Ferrini, 2006; Larney and Angers, 2012; Sloan et al., 2012). While organic soil amendments

435 immediately decrease $\rho_{\mathrm{b}}$ through a bulk dilution of mineral soil with organic material (Bassuk

436 and Rivenshield, 2007; Loper et al., 2010), the persistence of this effect has been questioned. In

437 the Arlington study, the small decreases in $\rho_{b}$ were likely due to this dilution effect, as aggregate

438 formation usually takes longer than the 13 months between installation and sampling(Wick et al.,

439 2009a). The soil rehabilitation procedure under study here differs from typical agricultural

440 amendment (surface application followed by shallow tillage) in three ways: 1) compost

441 incorporation is accomplished with a backhoe leading to much coarser mixing than tillage; 2)

442 compost is incorporated into the subsoil, to $60 \mathrm{~cm}$ in some cases; and 3) tree planting is part of

443 the rehabilitation practice based on the premise that roots will have access to newly opened soil

444 channels resulting from compost incorporation and root activity will facilitate movement of C

445 into more stable pools (Chen et al., 2013). Compost incorporation into deeper soil layers is

446 important in urban settings where cut and fill grading practices during land development may

447 result in multiple compacted soil lifts. Furthermore, even though subsurface soils may be highly

448 disturbed during initial urbanization, they are less likely than surface soils to be subjected to

449 either ongoing human impacts or plant root influences as these may be unlikely to penetrate

450 highly compacted soil regions (Day et al., 2000). This reduced surface interaction, however, also

451 contributes to the higher proportion of $\mathrm{C}$ in stable pools (i.e., physically or chemically protected) 
452 found in deeper soils (Lorenz et al., 2011). Nonetheless, addressing soil compaction with coarse

453 insertion of compost well below the soil surface may have significant benefits because it opens

454 up these soil regions to root penetration and thus ongoing C storage (Chen et al., 2013), greater

455 hydraulic conductivity (Chen et al., 2014b), and greater rooting space to support tree growth and

456 potentially increase tree stability—without excessive disruption of aggregates, especially

457 macroaggregates. However, in this study treatments did not always successfully reach the

458 intended soil depth, emphasizing the difficulty of achieving rehabilitation of compacted subsoils.

459 In the fully replicated plot study, observation through minirhizotrons installed for another

460 experiment immediately after treatment installation confirmed that compost had reached $60 \mathrm{~cm}$

461 depth in most, but not all locations. In the Arlington study, soil sampling clearly indicated that

462 compost incorporation had not been achieved to the specified depth. This indicates that in spite

463 of being provided with a written specification (Day et al., 2012), several teleconference and face-

464 to-face meetings with the project management team, and periodic site visits during installation,

465 the contractor did not install the SPR treatment to the depth mandated in the specification (i.e.,

466 that the backhoe bucket did not penetrate to the full $60 \mathrm{~cm}$ ). The method explored here is novel,

467 and it seems that ensuring that the contractor installed SPR to the unusually great depth of $60 \mathrm{~cm}$

468 was more difficult than expected. Because of the novelty of the SPR soil treatment, testing for

469 contractor compliance after installation by extracting samples with a push tube could be helpful.

470 In addition, the idea of site preparation, as opposed to planting hole preparation, was novel to

471 contractors and additional effort may be required to clearly communicate that SPR is to be

472 applied to the entire soil area, not just where trees are to be planted. 
473 The greatest reductions in $\rho_{\mathrm{b}}$ from SPR vs. conventional practice in both studies were seen at soil

474 depths where conventional practice (TP and CON) resulted in highly compacted soils and the

475 SPR subsoil disruption was fully implemented, at approximately $15-30 \mathrm{~cm}$ depth. These

476 differences persisted after 5 years, possibly due to the minimal disruption of aggregates in

477 comparison to traditional tillage, root exploration, and the eventual protection of

478 macroaggregates by organic matter additions (Grosbellet et al., 2011), although these were not

479 measured in this study. The slightly greater $\rho_{b}$ found near the bottom of the SPR treatment in

480 some cases may have been caused by the movement of the backhoe bucket during installation. In

481 the Arlington study, SPR resulted in increased macroaggregate-associated C after only one year,

482 confirming findings from an earlier analysis of soil aggregates in the plot study (Chen et al.,

483 2014b). Chen et al. (2014) reported higher macro-aggregate-associated C concentrations in SPR

484 treated soil at $15-30 \mathrm{~cm}$ depth than in simulated development four years after the installation of

485 SPR. We observed this same effect after only 13 months in this study. We saw no differences in

486 MWD among treatments after one year; similarly, Chen et al. (2014b) found no differences after

487 four and five years. Increases in macro-aggregate-associated C imply that C storage in the soil is

488 increasing; however, although mean C density of SPR plots was higher in Arlington, the

489 difference was not significant. Because the subsoil is loosened and disturbed during installation,

490 some existing organic $\mathrm{C}$ is likely to be lost (Wick et al., 2009b; Chen et al., 2014b), explaining

491 the increase in the macro-aggregate associated $\mathrm{C}$ and lack of change in total organic $\mathrm{C}$.

492 Contractors sometimes employ the ET treatment to reduce the abrupt soil interface that can result

493 from laying topsoil over a compacted subgrade. This tillage reduced $\rho_{\mathrm{b}}$ in surface soil at 8

494 months, but this effect did not persist at 5 years. A similar pattern was seen in SPR, which also

495 included surface tillage, although overall $\rho_{\mathrm{b}}$ was lower, likely due to some incorporation of 
496 residual compost. Tillage results in both reduced labile and recalcitrant $\mathrm{C}$ pools and disrupts soil

497 aggregates (Haynes, 2005; Chen et al., 2013), reflecting long-term costs that outweigh any

498 benefit garnered from short term reductions in soil density for urban tree planting.

499 The lack of differences in hydraulic conductivity of surface soils in Arlington was expected,

500 since surface treatments were virtually identical in SPR and control plots. Because measurements

501 of $\mathrm{K}_{\text {near }}$ were made under tension and do not represent flow in large macropores (Beven and

502 Germann, 2013), $\mathrm{K}_{\text {near }}$ and $\mathrm{K}_{\text {sat }}$ are not directly comparable. Chen et al.'s (2014b) earlier study

503 found $\mathrm{K}_{\text {sat }}$ was nearly 10 times higher than the typical practice at depths of $10-40 \mathrm{~cm}$, the depth

504 range most affected by SPR. Thus, we expected that differences in $\mathrm{K}_{\text {sat }}$ would occur at the 15-30

$505 \mathrm{~cm}$ depth, where compost was incorporated. That no effect was detectable may be due to the core

506 method we used to measure $\mathrm{K}_{\text {sat }}$. Because $\mathrm{K}_{\text {sat }}$ is scale- dependent and SPR results in

507 heterogeneous subsoil with soil clods interspersed with veins of compost, differences may have

508 been evident if $\mathrm{K}_{\text {sat }}$ had been measured in situ, or on a larger scale, where larger cracks or water

509 paths may have had more influence. We used the core method because of the difficulty of

510 conducting in situ measurements in dispersed urban plots.

511 As root growth is known to begin at soil temperatures around $4^{\circ} \mathrm{C}$ for some species (Kuhns et al.,

512 1985), and $12{ }^{\circ} \mathrm{C}$ for others species including Q. coccinea (Harris et al., 1995), we tested whether

513 there was a difference in the amount of time that in the paired temperature plots spent above

$51412^{\circ} \mathrm{C}$ : the difference was approximately 45 minutes over the course of a year and of no biological

515 consequence. Root growth is known to stop in the fall when soil temperatures reach 6 to $8^{\circ} \mathrm{C}$

516 (Harris et al., 1995). By these criteria, the root growth growing season was shifted by one day

517 later by SPR; again not of biological significance. The slight buffering of soil temperature we 
518 observed in SPR plots may be due to decreased thermal conductivity of amended soil due to

519 more air filled pores and increased water holding capacity, which could raise the amended soil's

520 specific heat capacity (Gupta et al., 1977).

\section{Conclusions}

522 We assessed the response of eight commonly planted urban tree species to soil rehabilitation.

523 Using a controlled plot study as well as a designed experiment at an urban site, this work

524 demonstrates that consideration of below-ground conditions is critical to development of

525 strategies to increase urban tree canopy cover through tree planting. Soil rehabilitation that

526 includes deep incorporation of compost such as soil profile rebuilding is a viable means to

527 improve establishment and increase growth rates of planted trees in disturbed, urbanized soils.

528 Response magnitude may be even greater when soils are more severely compacted.

529 Decreases in soil bulk density resulting from SPR persist over time. In addition, C sequestration

530 rates for the soil/plant system are increased on several fronts: more aggregate-associated C, more

531 soil C at depth; and greater net primary productivity of the site. Although there may be a very

532 slight buffering of soil temperature in rehabilitated soils, this effect is likely site specific and was

533 not of sufficient magnitude to meaningfully alter the below-ground growing season.

534 In addition to reducing soil compaction and increasing tree growth, soil rehabilitation shows

535 potential for improving stormwater capture of urban forests, although more data are needed in

536 more diverse planting situations to clearly quantify this effect. While other studies have

537 established that SPR enhances $\mathrm{K}_{\text {sat }}$, we were unable to replicate this finding in our field study in

538 Arlington, Virginia. However, this may serve more as an indicator of the heterogeneity of 
539 disturbed soils and the deliberate heterogeneity created by compost incorporation in SPR, rather

540 than a clear statement of the effect of SPR on $\mathrm{K}_{\text {sat. }}$. In such situations in situ field measurements

541 that capture conductivity characteristics of the bulk soil and its larger scale characteristics such

542 as root paths, cracks, or clods are valuable. The faster establishment of transplanted trees and

543 decreases in subsoil density found in these studies can allow for more water to be captured and

544 stored than in typical urban soil. Although tree physiological measurements did not reveal strong

545 differences in stress between treatments, trees in SPR plots were able to exploit the improved

546 below-ground conditions and establish more quickly. Faster tree establishment means faster

547 returns on investment for municipalities using trees and soil for ecosystem service provision.

548 Acknowledgements

549 To be provided

550

551 


\section{References}

554 Bassuk, N. L., Rivenshield, A., 2007. Using organic amendments to decrease bulk density and increase macroporosity in compacted soils. Arboriculture \& Urban Forestry 33, 140-146.

556 Beven, K., Germann, P., 2013. Macropores and water flow in soils revisited. Water Resources Research 49, 3071-3092.

Bolund, P., Hunhammar, S., 1999. Ecosystem services in urban areas. Ecological Economics 29, 293-301.

Boyle, M., Frankenberger, W., Stolzy, L., 1989. The influence of organic matter on soil aggregation and water infiltration. Journal of Production Agriculture 2, 290-299.

Brown, S., Cotton, M., 2011. Changes in soil properties and carbon content following compost application: results of on-farm sampling. Compost Science \& Utilization 19, 87-96.

564 Chen, Y., Day, S. D., Shrestha, R. K., Strahm, B. D., Wiseman, P. E., 2014a. Influence of urban land development and soil rehabilitation on soil-atmosphere greenhouse gas fluxes. Geoderma 226-227, 348-353.

Chen, Y., Day, S. D., Wick, A. F., McGuire, K. J., 2014b. Influence of urban land development and subsequent soil rehabilitation on soil aggregates, carbon, and hydraulic conductivity. Science of the Total Environment 494-495, 329-336.

Chen, Y., Day, S. D., Wick, A. F., Strahm, B. D., Wiseman, P. E., Daniels, W. L., 2013. Changes in soil carbon pools and microbial biomass from urban land development and subsequent post-development soil rehabilitation. Soil Biology \& Biochemistry 66, 38-44. 
575 Cogger, C. G., 2005. Potential compost benefits for restoration of soils disturbed by urban development. Compost Science \& Utilization 13, 243-251.

Day, S. D., Amateis, R. L., 2011. Predicting canopy and trunk cross-sectional area of silver linden (Tilia tomentosa) in confined planting cutouts. Urban Forestry \& Urban Greening $10,317-322$.

Day, S. D., Bassuk, N. L., 1994. A review of the effects of soil compaction and amelioration treatments on landscape trees. Journal of Arboriculture 20, 9-17.

Day, S. D., Layman, R. M., Chen, Y., Rolf, K., Harris, J. R., Daniels, W. L., Wiseman, P. E., McGuire, K. J., Strahm, B. D., Wick, A. F., Mauzy, B., 2012, Soil Profile Rebuilding Specification, Virginia Tech, http://urbanforestry.frec.vt.edu/SRES/specification.html, doi: 10.13140/RG.2.1.3503.3049.

Day, S. D., Seiler, J. R., Persaud, N., 2000. A comparison of root growth dynamics of silver maple and flowering dogwood in compacted soil at differing soil water contents. Tree Physiology 20, 257-263.

Denef, K., Six, J., Bossuyt, H., Frey, S. D., Elliott, E. T., Merckx, R., Paustian, K., 2001. Influence of dry-wet cycles on the interrelationship between aggregate, particulate organic matter, and microbial community dynamics. Soil Biology \& Biochemistry 33, 1599-1611.

Effland, W., Pouyat, R., 1997. The genesis, classification, and mapping of soils in urban areas. Urban Ecosystems 1, 217-228.

Galbraith, J., Donovan, P., 2005, Interactive GIS and Soil Survey of the Virginia Tech Kentland Farm in Montgomery County, Virginia, USDA-NRCS in cooperation with Virginia Polytechnic Institute and State University, doi: 
Gilbertson, P., Bradshaw, A. D., 1990. The survival of newly planted trees in inner cities. Arboricultural Journal 14, 287-309.

600

601

602

603

604

605

606

607

608

609

610

611

612

613

614

615

616

Grabosky, J., Gilman, E. F., 2004. Measurement and prediction of tree growth reduction from tree planting space design in established parking lots. Journal of Arboriculture 30, 154159.

Grosbellet, C., Vidal-Beaudet, L., Caubel, V., Charpentier, S., 2011. Improvement of soil structure formation by degradation of coarse organic matter. Geoderma 162, 27-38.

Gupta, S. C., Dowdy, R. H., Larson, W. E., 1977. Hydraulic and thermal properties of a sandy soil as influenced by incorporation of sewage sludge. Soil Science Society of America Journal 41, 601-605.

Harris, J. R., 2007. Transplanting large trees. CAB Reviews: Perspectives in Agriculture, Veterinary Science, Nutrition and Natural Resources 2,

Harris, J. R., Bassuk, N. L., Zobel, R. W., Whitlow, T. H., 1995. Root and shoot growth periodicity of green ash, scarlet oak, Turkish hazelnut, and tree lilac. Journal of the American Society for Horticultural Science 120, 211-216.

Haynes, R., 2005. Labile organic matter fractions as central components of the quality of agricultural soils: An overview. Advances in Agronomy 85, 221-268.

Hillel, D., 1982, Introduction to Soil Physics, Academic Press, Inc., San Diego, CA, 364. p189.

Jim, C. Y., 1998. Urban soil characteristics and limitations for landscape planting in Hong Kong. Landscape and Urban Planning 40, 235-249.

Khaleel, R., Reddy, K., Overcash, M., 1981. Changes in soil physical properties due to organic waste applications: A review. Journal of Environmental Quality 10, 133-141. 
Klute, A., Dirksen, C., 2003, Hydraulic conductivity and diffusivity: Laboratory methods, in: Methods of Soil Analysis: Part 1 (A. Klute, ed.), Soil Science Society of America, pp. 687-734.

Kozlowski, T., 1999. Soil compaction and growth of woody plants. Scandinavian Journal of Forest Research 14, 596-619.

Kuhns, M., Garrett, H., Teskey, R., Hinckley, T., 1985. Root growth of black walnut trees related to soil temperature, soil water potential, and leaf water potential. Forest Science 31, 617629.

Larney, F. J., Angers, D. A., 2012. The role of organic amendments in soil reclamation: A review. Canadian Journal of Soil Science 92, 19-38.

Loper, S., Shober, A. L., Wiese, C., Denny, G. C., Stanley, C. D., Gilman, E. F., 2010. Organic soil amendment and tillage affect soil quality and plant performance in simulated residential landscapes. HortScience 45, 1522-1528.

Lorenz, K., Lal, R., Shipitalo, M. J., 2011. Stabilized soil organic carbon pools in subsoils under forest are potential sinks for atmospheric $\mathrm{CO}_{2}$. Forest Science 57, 19-25.

Martens, D., Frankenberger, W., 1992. Modification of infiltration rates in an organic-amended irrigated. Agronomy Journal 84, 707-717.

McGee, J. A., Day, S. D., Wynne, R. H., White, M. B., 2012. Using geospatialtools to assess the urban tree canopy: decision support for local governments. Journal of Forestry 110, 275286.

McHale, M. R., Burke, I. C., Lefsky, M. A., Peper, P. J., McPherson, E. G., 2009. Urban forest biomass estimates: is it important to use allometric relationships developed specifically for urban trees? Urban Ecosystems 12, 95-113. 
643 Mincey, S. K., Schmitt-Harsh, M., Thurau, R., 2013. Zoning, land use, and urban tree canopy 644 cover: The importance of scale. Urban Forestry \& Urban Greening 12, 191-199.

645 Nowak, D. J., 2006. Institutionalizing urban forestry as a "biotechnology" to improve 646 environmental quality. Urban Forestry \& Urban Greening 5, 93-100.

647 Nowak, D. J., Dwyer, J. F., 2007, Understanding the Benefits and Costs of Urban Forest 648 Ecosystems, in: Urban and Community Forestry in the Northeast (J. E. Kuser, ed.), 649 Springer Netherlands, pp. pp 25-46.

650 Nowak, D. J., Greenfield, E. J., 2012. Tree and impervious cover change in U.S. cities. Urban 651 Forestry \& Urban Greening 11, 21-30.

652 Nowak, D. J., Kuroda, M., Crane, D. E., 2004. Tree mortality rates and tree population 653 projections in Baltimore, Maryland, USA. Urban Forestry \& Urban Greening 2, 139-147.

654 Nowak, D. J., McBride, J., Beatty, R. A., 1990. Newly planted street tree growth and mortality. 655 Journal of Arboriculture 16, 124-129.

656 Pavao-Zuckerman, M. A., 2008. The nature of urban soils and their role in ecological restoration 657 in cities. Restoration Ecology 16, 642-649.

Pitt, R., Lantrip, J., Harrison, R., Henry, C. L., Xue, D., O’Connor, T., 1999, Infiltration through disturbed urban soils and compost-amended soil effects on runoff quality and quantity, U.S. Environmental Protection Agency, Office of Research and Development, Washington, D.C. No. EPA/600/R-00/016., doi:

662 Randrup, T. B., Dralle, K., 1997. Influence of planning and design on soil compaction in 663 construction sites. Landscape and Urban Planning 38, 87-92.

664 Rawls, W., Pachepsky, Y. A., Ritchie, J., Sobecki, T., Bloodworth, H., 2003. Effect of soil 665 organic carbon on soil water retention. Geoderma 116, 61-76. 
666

Rolf, K., 1991. Soil improvement and increased growth response from subsoil cultivation. Journal of Arboriculture 17, 200-204.

Roman, L., Battles, J., McBride, J., 2014. The balance of planting and mortality in a street tree population. Urban Ecosystems 17, 387-404.

Roman, L. A., Scatena, F. N., 2011. Street tree survival rates: Meta-analysis of previous studies and application to a field survey in Philadelphia, PA, USA. Urban Forestry \& Urban Greening 10, 269-274.

Roy, S., Byrne, J., Pickering, C., 2012. A systematic quantitative review of urban tree benefits, costs, and assessment methods across cities in different climatic zones. Urban Forestry \& Urban Greening 11, 351-363.

Sæbø, A., Ferrini, F., 2006. The use of compost in urban green areas - A review for practical application. Urban Forestry \& Urban Greening 4, 159-169.

Seto, K. C., Güneralp, B., Hutyra, L. R., 2012. Global forecasts of urban expansion to 2030 and direct impacts on biodiversity and carbon pools. Proceedings of the National Academy of Sciences 109, 16083-16088.

Six, J., Bossuyt, H., Degryze, S., Denef, K., 2004. A history of research on the link between (micro)aggregates, soil biota, and soil organic matter dynamics. Soil and Tillage Research 79, 7-31.

Six, J., Elliot, E. T., Paustian, K., Doran, J. W., 1998. Aggregation and soil organic matter accumulation in cultivated and native grassland soils. Soil Science Society of America Journal 62, 1367-1377.

Sloan, J. J., Ampim, P. A. Y., Basta, N. T., Scott, R., 2012. Addressing the need for soil blends and amendments for the highly modified urban landscape. Soil Science Society of America Journal 76, 1133-1141. 
690 Sustainable Sites Initiative, 2014, SITES v2 Rating System, U.S. Green Building Council, 151.

691 Throop, H., Archer, S., Monger, H. C., Waltman, S., 2012. When bulk density methods matter: 692 Implications for estimating soil organic carbon pools in rocky soils. Journal of Arid 693 Environments 77, 66-71.

694 Wick, A. F., Huzurbazar, S. V., Stahl, P. D., 2009a. Use of Bayesian methods to model soil 695 aggregation in undisturbed semiarid grasslands. Soil Science Society of America Journal $696 \quad 73,1707-1714$.

697 Wick, A. F., Ingram, L. J., Stahl, P. D., 2009b. Aggregate and organic matter dynamics in 698 reclaimed soils as indicated by stable carbon isotopes. Soil Biology \& Biochemistry 41, $699 \quad 201-209$.

700 Zhang, R., 1997. Determination of soil sorptivity and hydraulic conductivity from the disk 701 infiltrometer. Soil Science Society of America Journal 61, 1024-1030.

702 Zill, D. G., 1985, Calculus with Analytic Geometry, Prindle, Weber \& Schmidt, Boston, 290297. 

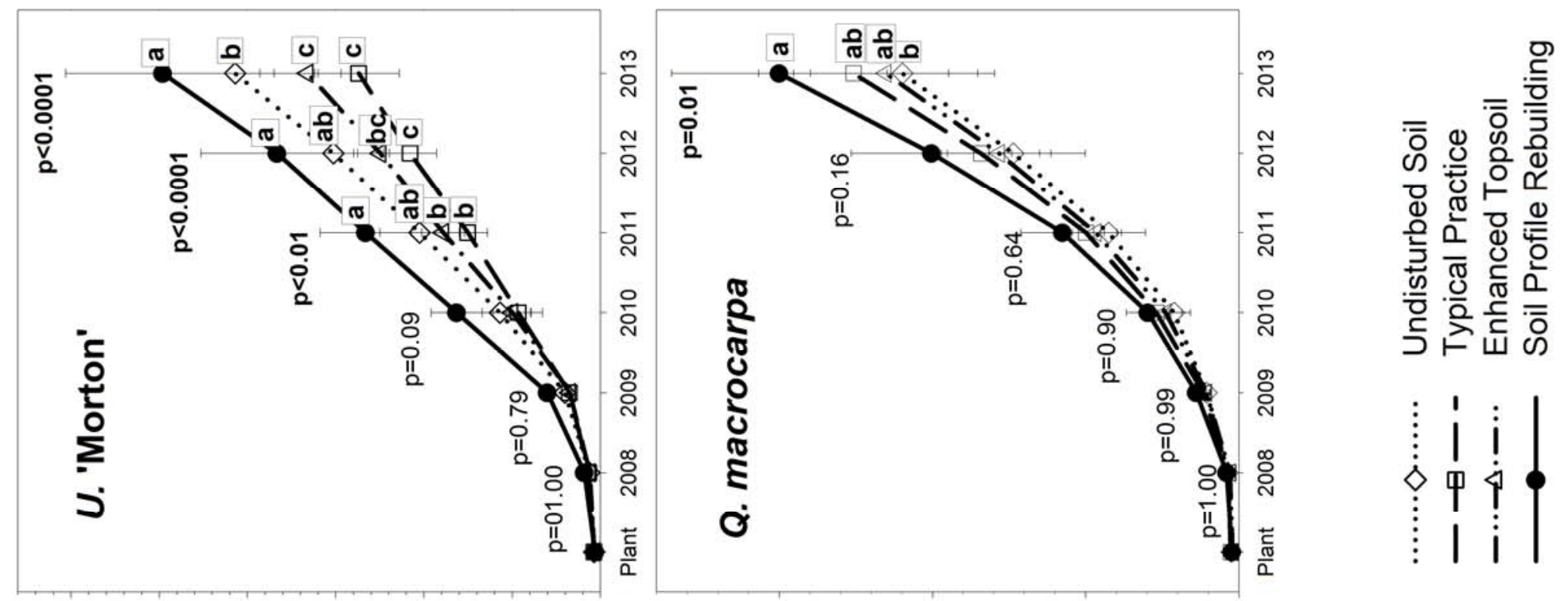

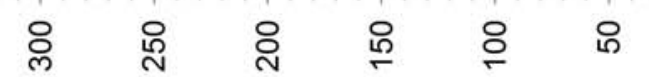

吕

요
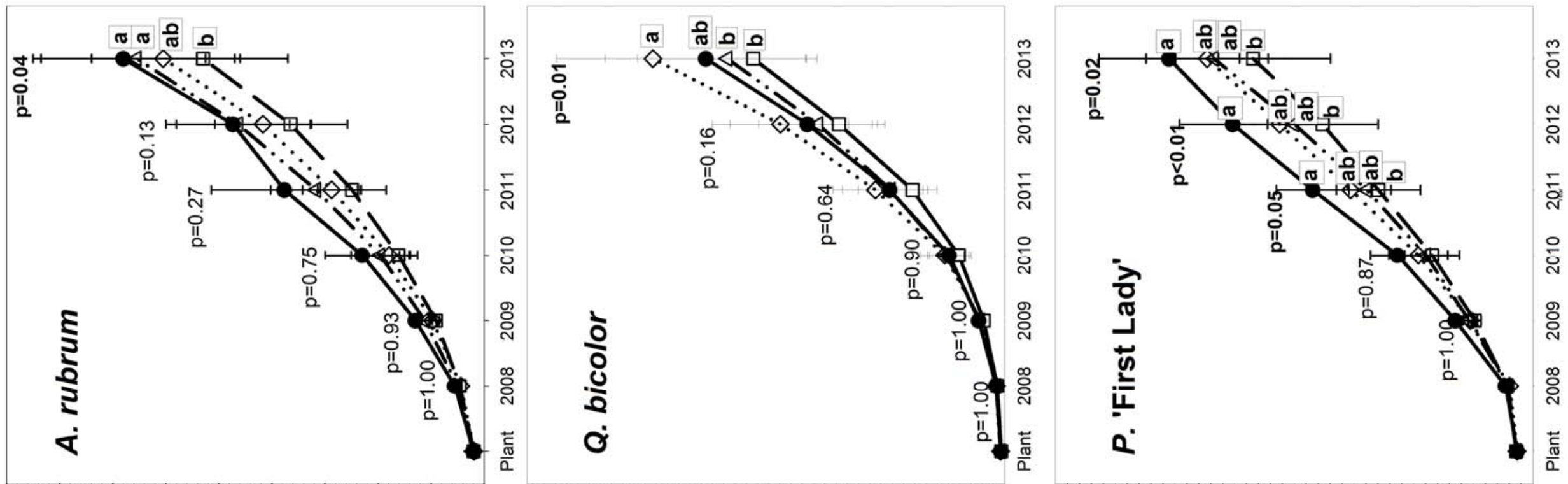

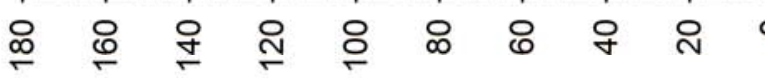

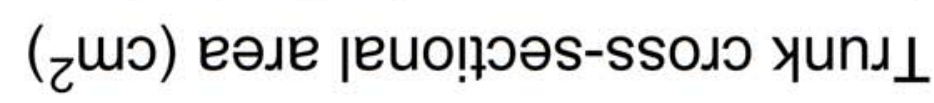



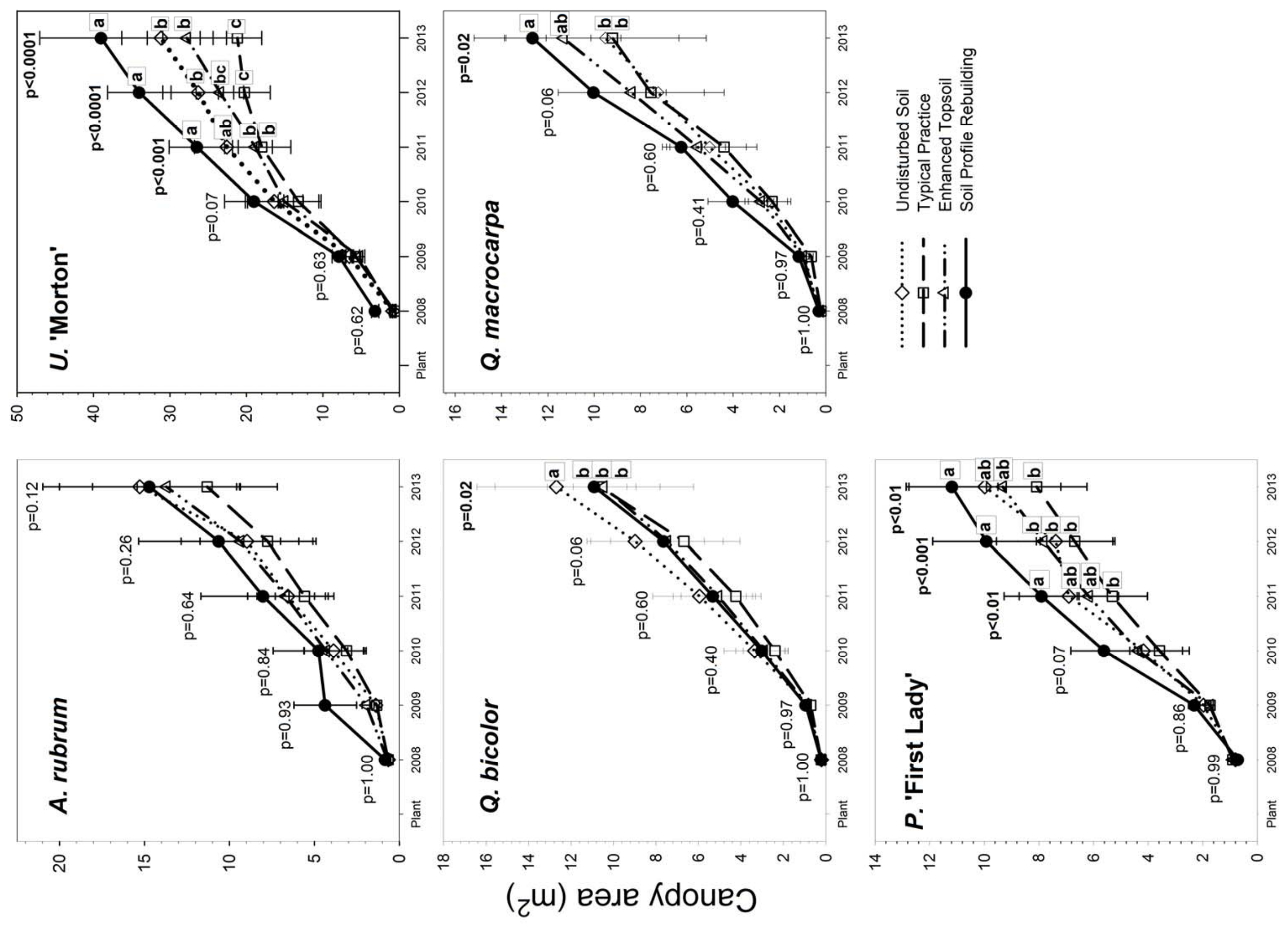


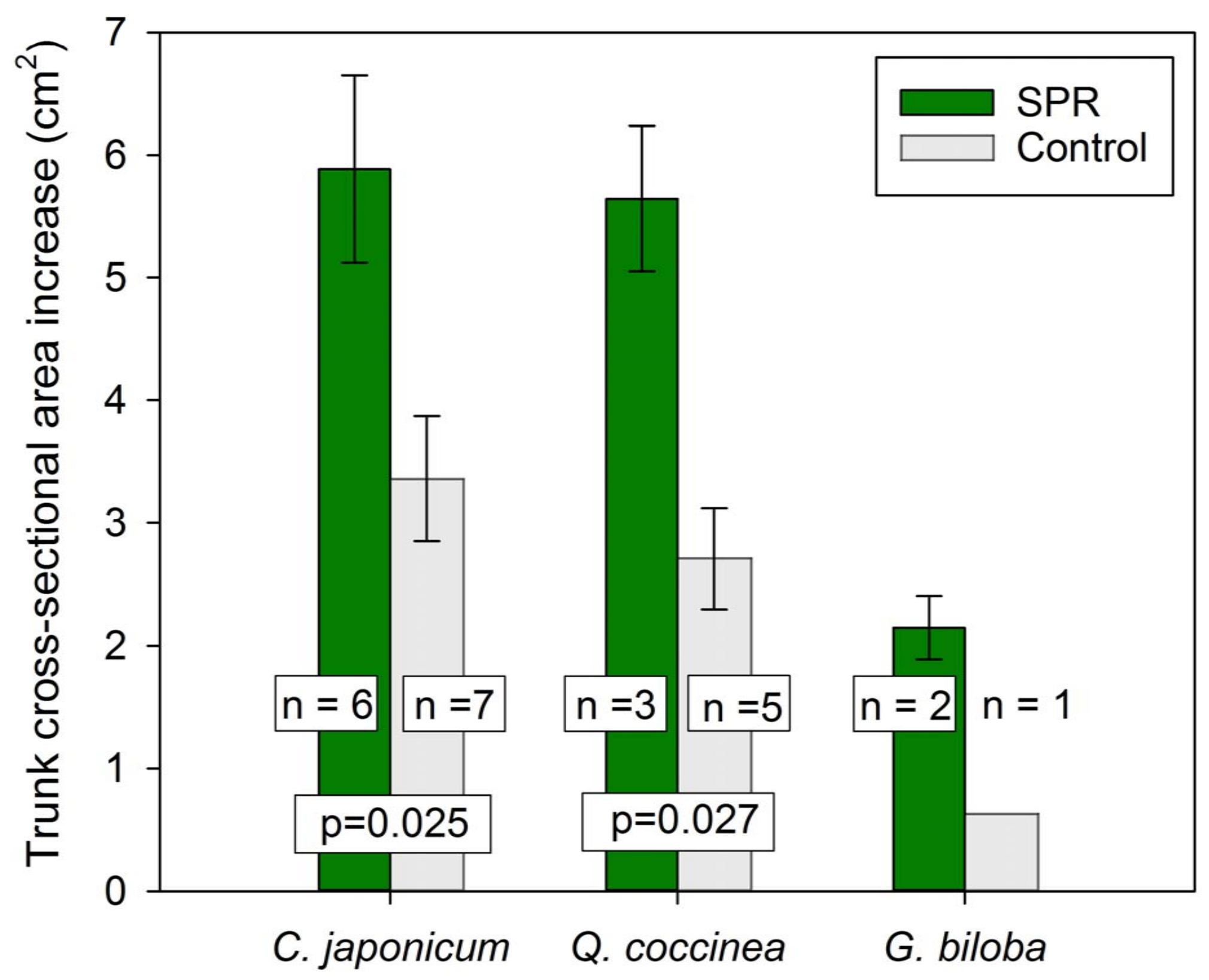


Table 1. Mean soil bulk density at four depths in soils that were not disturbed (UN; undisturbed), or subjected to typical land development practice and then not tilled (TP; typical practice), tilled (ET; enhanced topsoil), or rehabilitated with subsoiling and compost additions (SPR; soil profile rebuilding) 8 months and 5 years after installation. Numbers in parentheses indicate standard errors of the mean $(n=6)$. Letters indicate differences within each depth at $\alpha=0.05$ via Fisher's protected LSD.

\begin{tabular}{|c|c|c|c|c|c|c|c|c|}
\hline & \multicolumn{8}{|c|}{ Bulk Density $\left(\mathrm{Mg} \mathrm{m}^{-3}\right)$} \\
\hline & \multicolumn{8}{|c|}{ Soil depth $(\mathrm{cm})$} \\
\hline & \multicolumn{2}{|c|}{$2.5-7.5$} & \multicolumn{2}{|c|}{$15-20$} & \multicolumn{2}{|c|}{$31-36$} & \multicolumn{2}{|c|}{$51-56$} \\
\hline & $8 \mathrm{mos}$ & 5 yrs & $8 \mathrm{mos}$ & 5 yrs & $8 \mathrm{mos}$ & $5 \mathrm{yrs}$ & $8 \mathrm{mos}$ & 5 yrs \\
\hline UN & $1.52(0.04) \mathrm{a}$ & $1.43(0.02)$ & $1.65(0.02) b$ & 1.61 (0.02)ab & $1.69(0.03)$ & $1.72(0.02)$ & $1.62(0.08)$ & $1.70(0.02) \mathrm{b}$ \\
\hline $\mathrm{TP}$ & $1.51(0.02) \mathrm{a}$ & $1.38(0.07)$ & $1.91(0.03) \mathrm{a}$ & $1.76(0.04) a$ & $1.76(0.02)$ & $1.76(0.03)$ & $1.77(0.03)$ & $1.67(0.02) \mathrm{b}$ \\
\hline $\mathrm{ET}$ & $1.39(0.06) b$ & $1.44(0.03)$ & $1.84(0.04) \mathrm{a}$ & $1.68(0.04) \mathrm{a}$ & $1.69(0.03)$ & $1.72(0.02)$ & $1.76(0.01)$ & $1.68(0.01) \mathrm{b}$ \\
\hline SPR & $1.28(0.03) \mathrm{c}$ & $1.33(0.02)$ & $1.34(0.05) \mathrm{c}$ & $1.49(0.09) \mathrm{b}$ & $1.68(0.06)$ & $1.79(0.03)$ & $1.75(0.01)$ & $1.76(0.02) \mathrm{a}$ \\
\hline
\end{tabular}


Table 2. Mean integrated whole day water stress (I- $\Psi$ ) and photosynthesis (Ps) of A. rubrum and Q. bicolor transplanted in spring 2008 into soils that were not disturbed (UN; undisturbed), or subjected to typical land development practice and then not tilled (TP; typical practice), tilled (ET; enhanced topsoil), or rehabilitated with subsoiling and compost additions (SPR; soil profile rebuilding). Parentheses indicate standard errors of the mean $(n=6)$. Mean comparisons are within a day and species (within columns) at $\alpha=0.05$ via Fisher's protected LSD at $\mathrm{P}<0.10$.

\begin{tabular}{|c|c|c|c|c|c|c|}
\hline & \multicolumn{6}{|c|}{ Integrated Whole Day Water Stress (I- $\Psi)$} \\
\hline & \multicolumn{2}{|c|}{ Jul 192008} & \multicolumn{2}{|c|}{ Oct 12008} & \multicolumn{2}{|c|}{ Aug 15, 2009} \\
\hline & A. rubrum & Q. bicolor & A. rubrum & Q. bicolor & A. rubrum & Q. bicolor \\
\hline UN & $135.9(3.9)$ & $89.1(12.6)$ & $92.2(4.1)$ & 131.9 (4.9) & $98.5(3.4) b$ & $158.5(5.2)$ \\
\hline TP & $144.5(7.9)$ & $111.2(8.7)$ & $91.6(3.3)$ & $131.4(4.6)$ & $98.9(3.0) b$ & $169.9(7.2)$ \\
\hline ET & $141.8(4.5)$ & $103.4(7.4)$ & $92.0(3.3)$ & 131.5 (4.7) & $109.3(1.7) \mathrm{a}$ & $161.5(5.0)$ \\
\hline \multirow[t]{4}{*}{ SPR } & $137.7(6.8)$ & $108.7(6.7)$ & $84.8(4.2)$ & $123.1(7.1)$ & $115.8(3.4) \mathrm{a}$ & $170.4(6.0)$ \\
\hline & \multicolumn{6}{|c|}{ Ps $\left(\mu \mathrm{mol} \mathrm{CO} 2 \mathrm{~m}^{-2} \mathrm{~s}^{-1}\right)$} \\
\hline & \multicolumn{2}{|c|}{ May 272008} & \multicolumn{2}{|c|}{ September 132008} & \multicolumn{2}{|c|}{ Sept 22009} \\
\hline & A. rubrum & Q. bicolor & A. rubrum & Q. bicolor & A. rubrum & Q. bicolor \\
\hline UN & $4.78(1.63)$ & $4.17(0.72)$ & $11.86(0.81)$ & $12.58(0.80) \mathrm{c}$ & $10.31(0.65)$ & $16.28(0.90)$ \\
\hline TP & $5.78(1.15)$ & $4.15(0.38)$ & 12.66 (1.86) & $15.77(0.86) b$ & 10.64 (1.58) & 17.67 (1.25) \\
\hline ET & $4.77(0.84)$ & $3.77(0.45)$ & $12.88(0.50)$ & $15.50(0.81) b$ & 11.02 (1.73) & 15.72 (1.13) \\
\hline SPR & $5.80(0.64)$ & $3.82(0.53)$ & $13.14(2.02)$ & $19.51(0.88)$ a & $10.41(0.74)$ & $19.78(0.87)$ \\
\hline
\end{tabular}


Table 3. Soil bulk density, soil organic C, and aggregate-associated C (standard errors of the means in parenthesis) measured at four depths in soil profile rebuilding (SPR) and control plots in Arlington, Virginia 13 months after treatment installation. Data for $90-100 \mathrm{~cm}$ depth is estimated based on $60-90 \mathrm{~cm}$.

\begin{tabular}{|c|c|c|c|c|c|c|c|c|c|c|}
\hline \multirow{3}{*}{$\begin{array}{l}\text { Depth } \\
(\mathrm{cm})\end{array}$} & \multirow{2}{*}{\multicolumn{2}{|c|}{$\begin{array}{l}\text { Bulk Density } \\
\left(\mathrm{Mg} \mathrm{m}^{-3}\right)\end{array}$}} & \multirow{2}{*}{\multicolumn{2}{|c|}{$\begin{array}{l}\text { Total C Density } \\
\left(\mathrm{kg} \mathrm{C} \mathrm{m}^{-2}\right)\end{array}$}} & \multicolumn{6}{|c|}{ Sand-free Aggregate- Associated C ( $\mathrm{g} \mathrm{C} \mathrm{g}^{-1}$ aggregate) } \\
\hline & & & & & \multicolumn{2}{|l|}{$<250 \mu \mathrm{m}$} & \multicolumn{2}{|c|}{$2000-250 \mu \mathrm{m}$} & \multicolumn{2}{|l|}{$>2000 \mu \mathrm{m}$} \\
\hline & SPR & $\mathrm{CON}$ & SPR & $\mathrm{CON}$ & SPR & $\mathrm{CON}$ & SPR & $\mathrm{CON}$ & SPR & $\mathrm{CON}$ \\
\hline 0-15 & $\begin{array}{l}1.22 \\
(0.08)\end{array}$ & $\begin{array}{l}1.30 \\
(0.07)\end{array}$ & $\begin{array}{l}3.61 \\
(0.49)\end{array}$ & $\begin{array}{l}3.12 \\
(0.44)\end{array}$ & $\begin{array}{l}2.43 \times 10^{-2} \\
\left(3.7 \times 10^{-3}\right)\end{array}$ & $\begin{array}{l}3.18 \times 10^{-2} \\
\left(7.7 \times 10^{-3}\right)\end{array}$ & $\begin{array}{l}1.1 \times 10^{-1} \\
\left(2.4 \times 10^{-2}\right)\end{array}$ & $\begin{array}{l}7.24 \times 10^{-2} \\
\left(1.3 \times 10^{-2}\right)\end{array}$ & $\begin{array}{l}4.08 \times 10^{-2} \\
\left(4.9 \times 10^{-3}\right)\end{array}$ & $\begin{array}{l}4.35 \times 10^{-2} \\
\left(4.7 \times 10^{-3}\right)\end{array}$ \\
\hline $15-30$ & $\begin{array}{l}1.25 \\
(0.08)^{+}\end{array}$ & $\begin{array}{l}1.44 \\
(0.05)^{+}\end{array}$ & $\begin{array}{l}1.89 \\
(0.33)\end{array}$ & $\begin{array}{l}1.77 \\
(0.35)\end{array}$ & $\begin{array}{l}1.84 \times 10^{-2} \\
\left(2.6 \times 10^{-3}\right)\end{array}$ & $\begin{array}{l}1.61 \times 10^{-2} \\
\left(5.1 \times 10^{-3}\right)\end{array}$ & $\begin{array}{l}1.17 \times 10^{-1} \\
\left(3.0 \times 10^{-2}\right)^{*}\end{array}$ & $\begin{array}{l}5.16 \times 10^{-2} \\
\left(1.5 \times 10^{-2}\right)^{*}\end{array}$ & $\begin{array}{l}1.05 \times 10^{-1} \\
\left(3.3 \times 10^{-2}\right)^{\S}\end{array}$ & $\begin{array}{l}2.81 \times 10^{-2} \\
\left(8.8 \times 10^{-3}\right)^{\S}\end{array}$ \\
\hline $30-60$ & $\begin{array}{l}1.49 \\
(0.06)\end{array}$ & $\begin{array}{l}1.38 \\
(0.09)\end{array}$ & $\begin{array}{l}2.52 \\
(0.35)\end{array}$ & $\begin{array}{l}1.98 \\
(0.32)\end{array}$ & $\begin{array}{l}1.16 \times 10^{-2} \\
\left(1.7 \times 10^{-3}\right)\end{array}$ & $\begin{array}{l}1.16 \times 10^{-2} \\
\left(2.4 \times 10^{-3}\right)\end{array}$ & $\begin{array}{l}5.24 \times 10^{-2} \\
\left(1.1 \times 10^{-2}\right)\end{array}$ & $\begin{array}{l}3.68 \times 10^{-2} \\
\left(9.7 \times 10^{-3}\right)\end{array}$ & $\begin{array}{l}5.34 \times 10^{-2} \\
\left(2.7 \times 10^{-2}\right)\end{array}$ & $\begin{array}{l}8.5 \times 10^{-3} \\
\left(2.4 \times 10^{-3}\right)\end{array}$ \\
\hline $60-90$ & $\begin{array}{l}1.51 \\
(0.07)\end{array}$ & $\begin{array}{l}1.53 \\
(0.03)\end{array}$ & $\begin{array}{l}0.56 \\
(0.17)\end{array}$ & $\begin{array}{l}0.79 \\
(0.19)\end{array}$ & $\begin{array}{l}4.28 \times 10^{-3} \\
\left(1.4 \times 10^{-3}\right)\end{array}$ & $\begin{array}{l}1.06 \times 10^{-2} \\
\left(5.9 \times 10^{-3}\right)\end{array}$ & $\begin{array}{l}1.50 \times 10^{-2} \\
\left(9.3 \times 10^{-3}\right)\end{array}$ & $\begin{array}{l}2.40 \times 10^{-2} \\
\left(1.1 \times 10^{-2}\right)\end{array}$ & $\begin{array}{l}2.13 \times 10^{-2} \\
\left(1.3 \times 10^{-2}\right)\end{array}$ & $\begin{array}{l}1.04 \times 10^{-2} \\
(n=1)\end{array}$ \\
\hline \multicolumn{3}{|c|}{ 90-100 (estimated) } & $\begin{array}{l}0.18 \\
(0.06)\end{array}$ & $\begin{array}{l}0.26 \\
(0.07)\end{array}$ & & & & & & \\
\hline \multicolumn{3}{|c|}{ Total C density to $1 \mathrm{~m}$} & $\begin{array}{l}7.90 \\
(1.29)\end{array}$ & $\begin{array}{l}8.25 \\
(0.59)\end{array}$ & & & & & & \\
\hline
\end{tabular}

${ }^{+} \mathrm{p}=0.064$

${ }^{*} \mathrm{p}=0.071$

${ }^{\S} \mathrm{p}=0.087$ 